\title{
Redefined Innovation Ecosystem Promoting the Innovation Activities of the Hungarian Enterprises
}

\author{
Zoltán Birkner \\ National Research, Development and Innovation Office, Hungary \\ Zsófia Hartyányi \\ National Research, Development and Innovation Office, Hungary \\ Nora Rodek \\ University of Pannonia, Hungary
}

\section{Abstract}

Recognizing the global technological, societal and economical megatrends and challenges, national innovation systems have to be restructured to be more open and flexible. The European Union, its member states, including Hungary have to react as the competitiveness on regional and national level is deteriorating constantly compared to other leading regions in the world. New goals, tools and methods have to be implemented on national level as well. The Hungarian government targets to reshape the national innovation ecosystem with the aim to be more reflexive, sustainable and competitive. The actors (including universities, research centres and enterprises) have to redefine their roles and cooperate on a mutually beneficial basis. A redefined innovation ecosystem is planned to develop according to the Quintuple Helix which is not only a theoretical model but a functioning system. This study presents the steps the Hungarian government did toward an open innovation regulatory system, its RDI strategy as well as the results of our latest research conducted among Hungarian enterprises focusing on their innovation activities. The results show in what aspects the new strategy can support the needs of the businesses.

Keywords: innovation, innovation ecosystem, RDI strategy JEL classification: $\mathrm{O} 35$

\section{Introduction}

Due to global technological, societal and economic megatrends and challenges, national innovation systems must be transformed in order to make them more open, flexible and effective. The European Union, as an economic and political system has a lot to do in this regard, as evidenced by its lag apparent in the "European paradox": there is an alarming difference between the excellent European research results and the performance of actually realized innovation. This is also apparent in the gap between the bloc's potential and actual role in the global arena (European Commission, 1994; Rodríguez-Navarro-Narin, 2016; Argyropoulou et al., 2019).

In order to reduce its shortcomings, the EU strived to increase its R\&D and innovation expenditures (Europe 2020 Strategy). In 2017 the EU - even though overall outlays have seen a slight increase - was still way off from reaching the aimed target of annual 3\% of GDP investment into research and development, so increasing resources remains a top priority in the period post-2020 (Eurostat, 2017). 
EIS (European Innovation Scoreboard), issued annually by the European Commission, has proven to be the most authoritative tool for measuring the innovation performances of various EU member states. The scoreboard uses 27 indicators and approaches results from several perspectives - mainly those of human resources, financial outlays and measurement of process results, in order to offer a comprehensive review of national innovation systems.

The most cited overall index (Summary Innovation Index, SII) of the survey is a composite indicator that is calculated from the 27 basic indicators. According to the SII, Hungary is recognized as "moderate innovator", ranked in the third group out of the four categorized performance fields (Figure 1) This unfavorable position is mostly due to the weaknesses of the small and medium-sized enterprises.

Figure 1

SII Values of EU Member States in 2017

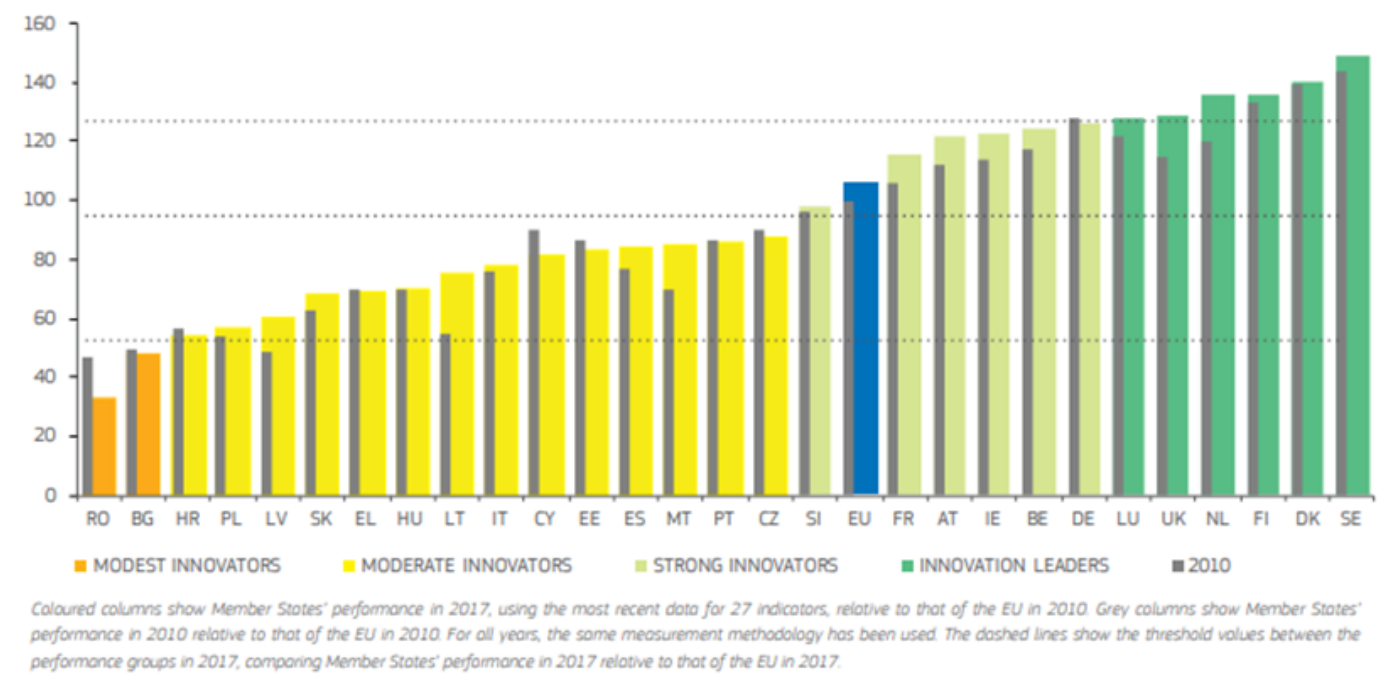

Source: European Innovation Scoreboard, 2018

According to the results obtained via the survey (Community Innovation Survey, 2017), that measures Hungarian companies' performance separately, only $25 \%$ of companies with 10-49 employees and 39\% of firms employing 50-249 people are considered innovative. Regarding Hungarian SMEs, the share of those active in production and process innovation, marketing and organizational innovation and internal innovation are low.

The Hungarian government established the Ministry for Innovation and Technology (MIT) in 2018, with the aim of elevating Hungary's innovation performance to the level of countries with significant innovation output. The most important professional state organization operating under the MIT is the National Research, Development and Innovation Office (NRDI Office) fully supports this goal. The NRDI Office created a uniform system for competitive tendering to coordinate and ensure resourceful and value-creating utilization of both EU development funds and innovation taxes paid by companies. The Office also recommends using the Quintuple Helix model as the basis of the innovation system's reform since this model considers a much broader collaboration system as a base requirement in order to enable companies to contribute more and adapt better to the new ecosystem (Carayannis et al., 2012; Birkner and Máhr, 2016). 
The results of the survey are aimed to support the evaluation of the competitive tendering system as well as the establishment of the new system.

\section{Methodology}

In 2019, the NRDI Office conducted a voluntary research survey via Limesurvey regarding contacts between the Office and companies related to it (i.e. which are in tendering contractual relations with it). At the time of the survey, the number of active corporate connections was 1200. 72 of these have filled out the survey and 31 of the companies which already had their tendering processes closed responded as well.

The main aims of the questionnaire-based survey were to analyze certain programmes that were announced to incentivize corporate R\&D and innovation utilizing EU resources and domestic tax income, as well as revising the calls system and reviewing the results of support already granted to beneficiaries. A further important aim of the survey was to develop the NRDI Office's programme portfolio through better understanding of calls applicants and to help the calls system operate as efficiently as possible as well as creating and introducing a methodology that supports businesses' innovation processes.

\section{Results}

Respondents were businesses that have handed in their proposal forms between 2013 and 2017. The share of the objectives of the calls for proposals, in which respondents have won support were as follows: corporate RDI $75 \%$, knowledge transfer $13 \%$, international cooperation $12 \%$. It is important to note that all of the respondents were businesses and considering that a large number of responses submitted came from the first category, it can be concluded that the overall share of candidates was the highest in said category (corporate RDI).

There were more than twice as many respondents in the status of ongoing projects $(69 \%)$ than ones that had already closed theirs $(31 \%)$, that shared their experiences and opinions.

Most of the projects (82\%) were realized in Central Hungary (Budapest - the country's capital - and its immediate surroundings make up this region).

Business size distribution of the respondents: almost half of them were small enterprises (45\%), almost a quarter of them were micro enterprises (22\%), mediumsized enterprises accounted for $18 \%$ and large businesses for $15 \%$. Analyzing the number of proposal submissions, it is seen that almost half of the candidates $(49 \%)$ applied once, $33 \%$ twice, while only $18 \%$ of the respondents applied thrice or on more occasions.

Most of the respondents were individual applicants (52\%). In case of consortiumbased application requirements, the ratio of consortium leaders and partners were $22 \%$ and $17 \%$, respectively, which can be considered balanced. 
Table 1

Connections between the Aim of the Call and Results of Projects (Number of Citations, in \%)

\begin{tabular}{|c|c|c|c|c|c|c|c|c|c|}
\hline 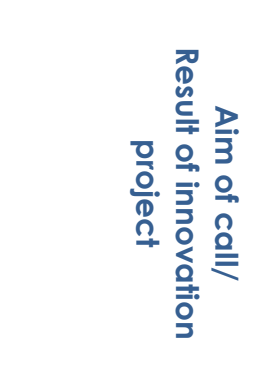 & 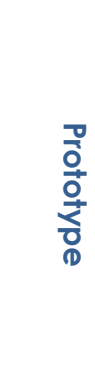 & $\begin{array}{l}\stackrel{D}{0} \\
\stackrel{D}{D} \\
\stackrel{T}{\longrightarrow}\end{array}$ & 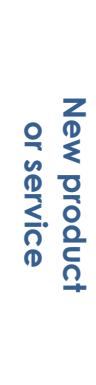 & 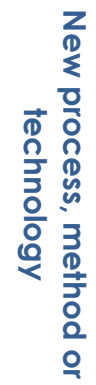 & 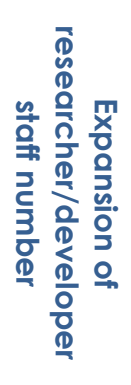 & 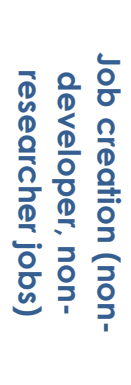 & 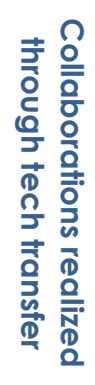 & 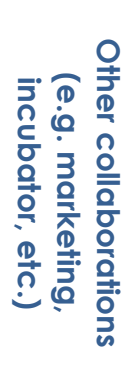 & 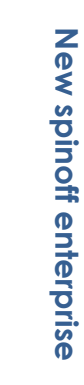 \\
\hline $\begin{array}{l}\text { Support for } \\
\text { corporate RDI } \\
\text { incentives }\end{array}$ & $32 \%$ & $3 \%$ & $13 \%$ & $9 \%$ & $23 \%$ & $10 \%$ & $6 \%$ & $4 \%$ & $0 \%$ \\
\hline $\begin{array}{l}\text { Support for } \\
\text { realization/impl } \\
\text { ementation of } \\
\text { knowledge } \\
\text { transfer }\end{array}$ & $11 \%$ & $6 \%$ & $5 \%$ & $8 \%$ & $34 \%$ & $6 \%$ & $23 \%$ & $5 \%$ & $2 \%$ \\
\hline $\begin{array}{l}\text { Support for } \\
\text { international } \\
\text { collaborations }\end{array}$ & $18 \%$ & $1 \%$ & $30 \%$ & $11 \%$ & $7 \%$ & $4 \%$ & $13 \%$ & $16 \%$ & $0 \%$ \\
\hline
\end{tabular}

Source: Authors' work

Examining the correlation between the objectives of the calls and the results of the innovation projects (see Table 1). it is obvious that in the category of corporate RDI incentives, prototype development is prevalent $(32 \%)$ as well as R\&D personnel expansion (23\%). Also, within this category can be seen the highest annual average ratio of before tax income increase (17\%).

In the knowledge transfer category, it can be ascertained that besides the expanse in the number of researchers (34\%), collaborations created within tech transfer framework are also among the most definitive $(23 \%)$, while the increase in before tax results is lower compared to the other categories.

In the case of international collaborations, new product or service creation is prevalent, but the category of prototypes is also prominent (18\%). In this category the increase in before tax income (11.25\%) is higher than in the previous one.

Among the responding applicants, the reasons they started their innovation projects were as follows: preserving or improving competitiveness (20\%), utilizing new business opportunities (20\%) and considering them part of their business strategy (16\%).

\section{Conclusion}

It can be concluded that supporting corporate NRDI incentives contributed to creating more prototypes, increased the number of R\&D staff as well as before tax income. Supporting the creation of knowledge transfer increased the number of R\&D staff and as well as the number of collaborations within the technology transfer framework. The most popular targets show what motivations incentivize businesses to launch RDI projects. Incentivizing similar activities among companies that do not pursue RDI activities, the share of businesses that take on innovation projects can be increased. The authors' aim is to introduce further results of processes still in progress, such as those of promoting increased effectiveness within the calls system and working out methodology for supporting the innovation processes of businesses. This 
more extensive study about the aforementioned results is expected to be published by the end of summer. The authors are convinced that these results shall prove to be informative to innovation experts of all countries that share similar capabilities as Hungary.

\section{References}

1. Argyropoulou, M., Soderquist, K. E., loannou, G. (2019), "Getting out of the European Paradox trap: Making European research agile and challenge driven", European Management Journal, Vol. 37, No. 1, pp. 1-5.

2. Birkner, Z., Máhr, T. (2016), "Interpreting innovation - in another way", Vezetéstudomán - Budapest Management Review, Vol. 47, No. 10, pp. 39-50.

3. Carayannis, E. G., Barth, T. D., Campbell, D. F. (2012), "The Quintuple Helix innovation model: global warming as a challenge and driver for innovation", Journal of Innovation and Entrepreneurship, Vol. 1, No. 1.

4. Community Innovation Survey (2017), available at: https://ec.europa.eu/eurostat/web/products-eurostat-news/-/DDN-20170124-2 (04 April 2019).

5. European Commission (1994), "First European report on science and technology indicators", Directorate-general XII, science, research, and development, Office for official publications of the European community, Luxembourg.

European Innovation Scoreboard (2018), available at: http://ec.europa.eu/growth/industry/innovation/factsfigures/scoreboards/index_en.htm (24 March 2019).

6. Eurostat (2017), "Total intramural R\&D expenditure (GERD) by sector of performance", available at: https://rio.jrc.ec.europa.eu/en/stats/total-intramural-rd-expendituregerd-sector-performance (27 March 2019).

7. Rodríguez-Navarro, A., Narin, F. (2016), "European paradox or delusion-are European science and economy outdated?", Science and Public Policy, Vol. 45, No. 1, pp. 1423.

\section{About the authors}

Zoltán Birkner, $\mathrm{PhD}$, is an associate professor at University of Pannonia Nagykanizsa Campus, a research specialist in the field of innovation performance of companies and regions and the manager of a water technology research and development center. The author can be contacted at zoltan.birkner@nkfih.gov.hu.

Zsófia Hartyányi is an innovation management officer at the National Research, Development and Innovation Office. She received her degree in International Business and Marketing Communication at John von Neumann University. She is responsible for program planning and RDI strategy. She is also the National Contact Point and Program Committee Member of H2O2O "Smart, green and integrated transport". The author can be contacted at zsofia.hartyanyi@nkfih.gov.hu.

Nora Rodek, PhD, is a senior lecturer at University of Pannonia Nagykanizsa Campus. She received her PhD in Management and Business Administration at the Doctoral School of University of Pannonia. Her research topics are CSR (Corporate Social Responsibility), sustainable and responsible management, social innovation. The author can be contacted at rodek.nora@uni-pen.hu. 